\title{
ЕНЕРГЕТИЧНИЙ АНАЛІЗ КОМПЛЕКСОУТВОРЕННЯ АРОМАТИЧНИХ МОЛЕКУЛ У ВОДНОМУ РОЗЧИНІ
}

\author{
В.В. КОСТЮКОВ, Н.М. ТВЕРДОХЛІБ, М.П. ЄВСТИГНЄЕВ
}

УДК 536.75

(C) 2011
Севастопольський національний технічний університет

(Вул. Університетсъка, 33, Севастополь 99053)
Представлено аналіз енергетики нековалентних взаємодій при самоасоціації 12 ароматичних молекул, різних за структурою та зарядом. Розроблено методику обчислення внесків різних фізичних чинників у повну енергію Гіббса. Виявлено, що внески водневих зв'язків та ентропійні чинники завжди сприятливі, тоді як ван-дер-ваальсівські, електростатичні та (або) гідрофобні взаємодії можуть бути стабілізуючими чи дестабілізуючими чинниками залежно від досліджуваної системи. Аналіз, який проведено у даній роботі, дає відповідь на питання: які чинники стабілізують/дестабілізують стекінг ароматичних молекул у розчині та яка їх відносна важливість.

\section{1. Вступ}

Взаємодії між ароматичними молекулами є одними з найбільш поширених у природних та синтетичних молекулярних системах. У водному розчині взаємодії між ароматичними кільцями (стекінг) приводять до утворення стопок завдяки їх пласкій формі та сприятливому гідрофобному внескові. Відомо, що стекінг є ключовим чинником стабільності нуклеїнових кислот [1], при зв'язуванні ДНК з лігандами [2], формуванні надмолекулярних структур з ароматичних доменів [3] та молекулярному впізнаванні [4].

Важливу інформацію щодо стекінгу можна отримати 3 термодинамічного (енергетичного) аналізу, який є предметом досліджень впродовж багатьох років для ароматичних систем $[4,5]$. Нині за допомогою добре розроблених методів досягнуто високої точності вимірювань основних термодинамічних параметрів (вільна енергія Гіббса $\Delta G$, ентальпія $\Delta H$, ентропія $\Delta S$ ). У практиці досліджень аналіз термодинамічних параметрів часто вимагає виділення з їх структури внеску окремих фізичних чинників у реакції комплексоутворення молекул - так звана проблема розкладення повної енергії Гіббса на складники [5]. Обчислення внесків різних фізичних чинників у повну енергію Гіббса при стекінгу ароматичних молекул може бути виконано з використа- нням різноманітних методик, досить добре розроблених різними авторами (див. нижче). Однак існують щонайменше дві фундаментальні проблеми при використанні цих даних у термодинамічному аналі3i:

1. Аналіз експериментально виміряних вільних енергій Гіббса, ентальпій та ентропій може не бути значущим, коли (зазвичай) виконується порівняння систем, різних за структурними або фізичними особливостями. Це зумовлено тим, що фізичні чинники, які створюють повні енергії нековалентних міжмолекулярних взаємодій, пов'язані між собою явищем ентальпійно-ентропійної компенсації [6]. Тому будь-які висновки щодо взаємозв'язку між відомими відмінностями досліджуваних систем та їх загальнотермодинамічними параметрами можуть бути не справедливими.

2. Величини теоретично обчислених вілъних енергій Гіббса, ентальпій та ентропій, віднесених до специфічних фізичних чинників, також можуть бути не значущими. Для складних систем при розрахунку енергій взаємодій зазвичай використовуються напівемпіричні підходи, засновані на параметризації цих взаємодій (так звані “силові поля"). Однак обчислені енергії залежать від початкової структури, параметрів силових полів, обмежень та методики молекулярного моделювання, що використовуються при аналізі. Хоча варіації розрахованих енергій можуть бути коректно передбачені, це майже не дає гарантії того, що обчислені величини енергій відповідають реальній ситуації у розчині. Фундаментальною причиною цього є те, що неможливо незалежно виміряти внески специфічних фізичних чинників у повні енергіі стекінгу. Тому у загальному випадку порівняння різних внесків у повну енергію $є$ ненадійним. Це означає, що відповідь на питання: які фізичні чинники стабілізують/дестабілізують стекінг ароматичних молекул у розчині та яка їх відносна важливість, на даний час не може бути дана однозначно. Наприклад, у літературі триває довга дискусія щодо питання, які сили 
(ван-дер-ваальсівські, електростатичні або гідрофобні) або типи взаємодій (з розчинником або міжмолекулярні) переважають при ароматичному стекінгу $[7,8]$.

Ми вважаємо, що ці проблеми термодинамічного аналізу можуть бути частково подолані, якщо методика обчислень енергетичних внесків головних фізичних чинників (розкладання вільної енергії) задовольняе такі умови:

1. Підсумовування незалежно обчислених енергетичних складників відтворює експериментально виміряну енергію взаємодії у межах розумних похибок. У цьому випадку обчислені величини енергій від різних фізичних чинників можуть бути використані у порівняльному аналізі.

2. Розрахунки повинні бути проведені для набору молекулярних систем, що відрізняються за структурою та зарядом. Якщо методика демонструє задовільний збіг з експериментом тільки для однієї системи або сукупності однотипних за структурою систем (як це часто і відбувається), то її перенесення на інші системи завжди буде сумнівним, без гарантії того, що обчислені енергії взагалі є значущими.

3. Обчислення повинні бути виконані з використанням однієї й тієї ж методики та набору параметрів/обмежень для кожної з досліджуваних систем. Інакше це може означати штучну підгонку результатів розрахунків, що робить обчислені енергії менш надійними.

У літературі існує вельми мало повідомлень щодо розділення повної енергії для різних молекулярних систем: білок-білок [9], білок-ліганд [10], ліганд-ДНК $[11,12]$ та ліганд-ліганд $[8,13,14]$. Але жодне з цих досліджень не задовольняє викладені вище умови. Ці обчислення засновані на використанні повної енергії Гіббса (як у [11]), або виконані для однієї системи (як у $[8-10,12])$, чи без урахування розчинника (як у $[13$, 14]). Вдалу спробу створення та застосування методики, що задовольняє три викладені вище умови, було нещодавно зроблено нами для комплексоутворення ароматичних лігандів з ДНК [15]. Метою даної роботи є адаптація цієї методології для розв'язання задачі розділення енергії реакцій комплексоутворення різних за структурою та повним електричним зарядом ароматичних молекул у водному розчині. Відомо, що ароматичні сполуки утворюють стопкові агрегати ("сандвічі" або "стекінг-комплекси") у розчині (див. огляди $[16,17])$ - процес, який називають самоасоціацією або димеризацією, та можуть слугувати прототипами стекінг-взаємодій (або $\pi-\pi$ взаємодій) між іншими ароматичними системами.

\section{2. Методи}

\section{1. Загалъний підхід до розділення енергії}

Реакції нековалентного утворення самоасоціату (димерного комплексу) $X_{2}$ з двох молекул $X$ приводять до динамічної рівноваги $X$ та $X_{2}$ у розчині:

$X+X \stackrel{\Delta G_{\text {total }}}{\longleftrightarrow} X_{2}$.

Реакція (1) характеризується рівноважною константою комплексоутворення $K$ та повною вільною енергією Гіббса $\Delta G_{\text {total }}$, яка може бути виміряна експериментально. Енергія Гіббса складається з внесків різних фізичних чинників. Усі відомі головні внески у $\Delta G_{\text {total }}$ у реакції (1) можуть бути підсумовані у виразі, що розділяе $\Delta G_{\text {total }}$ у термінах складників енергії від різних фізичних чинників:

$$
\begin{aligned}
& \Delta G_{\text {total }}=\Delta G_{\mathrm{VdW}}+\Delta G_{\mathrm{el}}+\Delta G_{\mathrm{hyd}}+ \\
& +\Delta G_{\mathrm{HB}}+\Delta G_{\mathrm{entr}}
\end{aligned}
$$

де нижні індекси означають енергетичні внески від ван-дер-ваальсівських, електростатичних, гідрофобних сил, водневих зв'язків та специфічних чинників переважно ентропійної природи відповідно. Слід відзначити, що розділення $\Delta G_{\text {total }}$ у (2) на "різні фізичні чинники" є умовним, оскільки всі ентальпійні складові у цьому рівнянні мають єдину електромагнітну природу. Більш детальний опис фізичного сенсу кожної з складових рівняння (2) буде дано нижче.

Рівняння (2) є основою методології, розвиненої у даній роботі. Якщо обчислення задовольняють три вимоги, викладені у вступі, більш глибокий аналіз кожної енергетичної складової в (2) забезпечує відповідь на головне питання: які фізичні чинники стабілізують/дестабілізують стекінг ароматичних молекул у розчині та яка їх відносна важливість.

Припускаючи відсутність конформаційних змін у жорсткому хромофорі ароматичних молекул $X$ при процесі їх комплексоутворення у водному розчині, обчислення кожного складника в (2) може бути виконано за термодинамічним циклом (рис. 1). Основною особливістю даного циклу $є$ розрахунок вільної енергї окремо у вакуумі (міжмолекулярна складова $\Delta G_{\text {im }}$ ) та у водній фазі (сольватаційна складова $\Delta G_{\text {solv }}$ ), які пов'язані рівнянням $\Delta G_{\text {total }}=\Delta G_{\mathrm{im}}+\Delta G_{\mathrm{solv}}^{X_{2}}-2 \Delta G_{\mathrm{solv}}^{X}$. Це співвідношення може бути спрощене:

$\Delta G_{\text {total }}=\Delta G_{\text {im }}+\Delta G_{\text {solv }}$ 


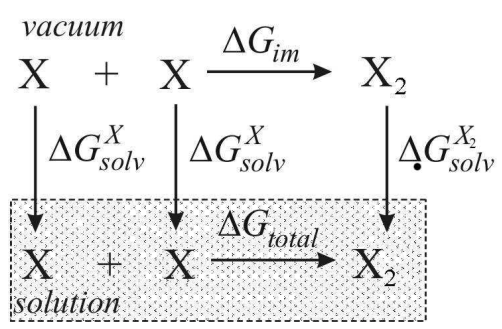

Рис. 1. Термодинамічний цикл для обчислення енергетичних термів

де $\Delta G_{\mathrm{solv}}=\Delta G_{\mathrm{solv}}^{X_{2}}-2 \Delta G_{\mathrm{solv}}^{X}$ та відображає внесок взаємодії з розчинником.

Таким чином, рівняння (2) та (3) забезпечують дві стратегії розділення повної енергії, а саме:

1. Розкладення у термінах фізичних чинників, задіяних у процесі комплексоутворення (рівняння (2)).

2. Розкладення у термінах міжмолекулярних (у вакуумі) взаємодій та з розчинником (рівняння (3)).

Обчислення кожної енергетичної складової у (2), (3), взагалі-то, на даний час є добре розвиненим як на $a b$ initio, так і на напівемпіричному рівнях (див. огляд [18]). Використання методів ab initio вимагає добре вивчених статичних структур, що обмежує їх відносно простими молекулами та робить неефективними для вивчення взаємодій з розчинником. Напівемпіричні методи, які засновані на моделюванні молекулярної динаміки (МД), мають обмежену точність, але забезпечують рішення цих проблем і здатні враховувати водне оточення та реально існуюче усереднення енергій за часом у процесі теплового руху. За нашими даними при єдиній вдалій спробі розділення повної енергії стекінгу ароматичних молекул у розчині використовували поєднання ab initio та напівемпіричного підходів, хоча це завдання було вирішене лише для одного типу відносно простих ароматичних молекул ферохіну та хлорохіну [8].

$\mathrm{У}$ даній роботі використано поєднання різних напівемпіричних підходів для демонстрації можливості розділення повної енергії для набору молекул з різними структурами та зарядами.

\section{2. Вибір досліджуваних молекул}

У даній роботі було вивчено ароматичні молекули (далі - ліганди, рис. 2), які утворюють самоасоціати шляхом $\pi-\pi$ стекінгу, що підтверджено різними експериментальними методами (див. [19, 20] та посилання у них):
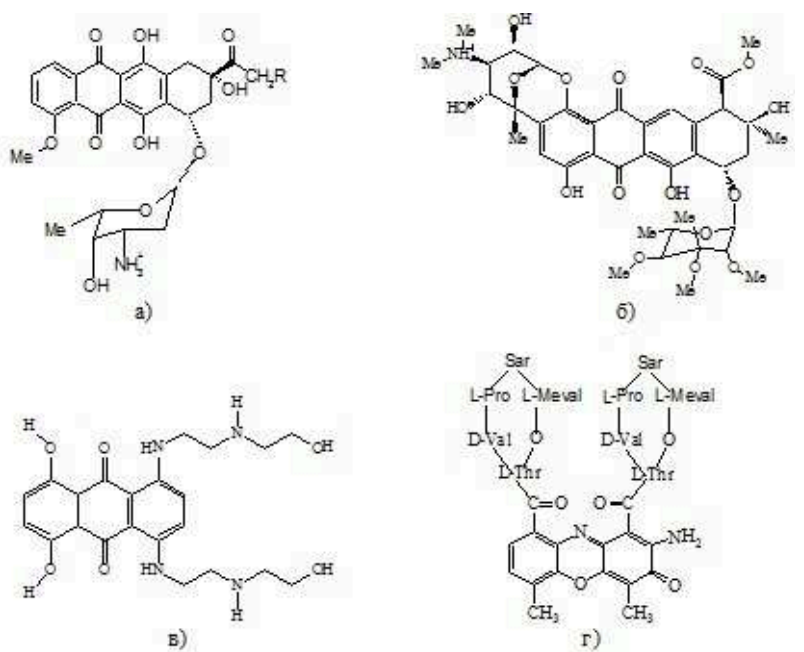

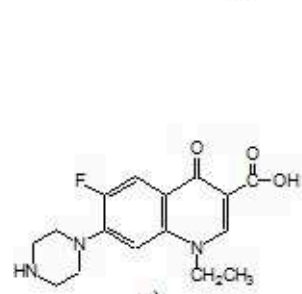

д)



e)

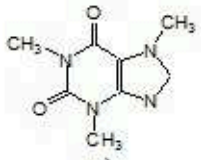

ж)
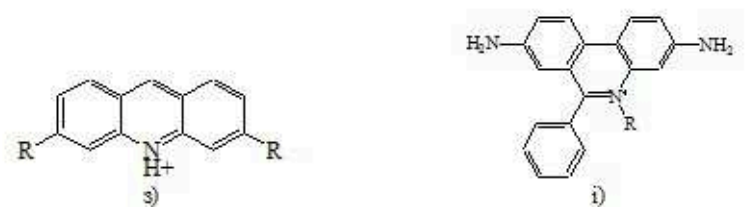

Рис. 2. Структури молекул, досліджених у роботі: $a$ - дауноміцин $(\mathrm{DAU}, \mathrm{R}=\mathrm{H})$, доксорубіцин $(\mathrm{DOX}, \mathrm{R}=\mathrm{OH}) ; \sigma$ ногаламіцин (NOG); $в$ - новантрон (NOV); 2 - актиноміцин D (AMD); $\partial-$ норфлоксацин (NOR); $e-$ флавінмононуклеотид (FMN); ж - кофеїн (CAF); з - профлавін $\left(\mathrm{PF}, \mathrm{R}=\mathrm{NH}_{2}\right)$, акридиновий оранжевий $\left(\mathrm{AO}, \mathrm{R}=\mathrm{N}\left(\mathrm{CH}_{3}\right)_{2}\right) ; i$ - бромистий етидій $\left(\mathrm{EB}, \mathrm{R}=\mathrm{CH}_{2} \mathrm{CH}_{3}\right)$, йодистий пропидій (PI, $\left.\mathrm{R}=\left(\mathrm{CH}_{2}\right)_{3} \mathrm{~N}^{+}\left(\mathrm{CH}_{2} \mathrm{CH}_{3}\right)_{2} \mathrm{CH}_{3}\right)$

- антибіотики дауноміцин (DAU), доксорубіцин (DOX), ногаламіцин (NOG), новантрон (NOV), норфлоксацин (NOR), актиноміцин D (AMD);

- мутагени профлавін (PF), акридиновий оранжевий $(\mathrm{AO})$, бромистий етидій $(\mathrm{EB})$, йодистий пропідій $(\mathrm{PI})$; - харчові молекули кофеїн (CAF) і вітамін флавінмононуклеотид (FMN).

У контексті проблеми розділення енергії вибір цих молекул зумовлений такими причинами:

1. Міжмолекулярна нековалентна асоціація формує основний молекулярний механізм зміни біологічної активності ароматичних сполук при їх застосуванні у поєднанні одна з одною [20], приводить до покращання розчинності погано розчинних сполук [21] та 
утворення деяких надмолекулярних структур, що є біологічно і технологічно важливим [22]. Тому знання внесків різних фізичних чинників у енергію асоціації є важливим для розуміння стабільності таких комплексів у водному середовищі.

2. Для всіх цих молекул структури самоасоціатів та величини вільної енергії Гіббса отримані при одних і тих же умовах розчинника та проаналізовано одними і тими ж методами. Ці результати наводяться у літературі (див. посилання у табл. 5) та є дуже якісними початковими даними для аналізу.

\section{3. Молекулярна динаміка}

Обчислення теплової динаміки самоасоціатів ароматичних молекул виконано з використанням програми $X$-PLOR [23]. Усі структури комплексів, використані у даній роботі, отримано шляхом мінімізації енергії у водному боксі за допомогою (у ролі початкових обмежень) індукованих протонних хімічних зсувів та протон-протонних крос-піків ядерного ефекту Оверхаузера, як описано у [24]. Оптимізацію геометрії комплексів виконано шляхом мінімізації потенціальної енергї методом спряжених градієнтів. При розрахунках ван-дер-ваальсівських і електростатичних взаємодій використано перемикаючу (switching) та зсуваючу (shifting) функції, відповідно, з радіусом обмеження $12 \AA$ [25]. Атомні заряди всіх лігандів обчислено методом Мерца-Коллмана [26] на рівні теоріі DFT (B3LYP) з базисним набором 6-31G*. Параметри нековалентних взаємодій відповідали силовому полю MM3 [27].

На першому етапі мінімізації енергї фіксували координати атомів лігандів з метою сприяння релаксації молекул води до їх рівноважних положень. Другу стадію мінімізації енергії виконували з фіксованими молекулами води. Кінцевий етап оптимізації геометрії проводили без будь-яких обмежень на рухи атомів системи.

Після мінімізації потенціальної енергії виконано процедуру МД за алгоритмом Verlet [28] при сталій температурі 298 K. Для застосування часового кроку 2 фс використано обмеження рухів атомів гідрогену за допомогою процедури SHAKE [29]. Під час МД молекули зовнішнього шару водного боксу фіксувалися для перешкоджання вильоту молекул води у зовнішній вакуум. Час еволюції для кожної системи становив 80 пс. Координати всіх атомів зберігалися через кожну 1 пс.

\section{4. Обчислення ван-дер-ваалъсівсъкої енергї}

Ван-дер-ваальсівські (ВДВ) взаємодії є ентальпійними за своєю природою. У даній роботі ВДВ енергію розраховували за допомогою потенціалу ЛенардаДжонса, який неявно враховує дисперсійну, індукційну, орієнтаційну складові та відштовхування оболонок атомів і найбільш часто використовується при молекулярному моделюванні взаємодій у водному середовищі:

$G_{\mathrm{VdW}}=\frac{A}{r^{12}}+\frac{B}{r^{6}}$

де $r$ - відстань між взаємодіючими атомами, $A$ і $B$ - параметри відштовхування та тяжіння відповідно, що залежать від типу атомів та їх хімічного оточення i відповідає силовому полю AMBER, що використовується при моделюванні.

$G_{\mathrm{VdW}}$ обчислювали з траєкторій МД у програмі $X$ PLOR шляхом усереднення протягом останніх 40 пс еволюції системи.

\section{5. Обчислення електростатичної енергї̈}

Під електростатичною енергією у даній роботі розуміють енергію взаємодії парціальних зарядів атомів лігандів, молекул води та іонів солі, присутніх у розчині. Розрахунок електростатичної енергії $\Delta G_{\text {el вико- }}$ нували за допомогою розв'язання нелінійного рівняння Пуассона-Больцмана (НРПБ) за допомогою програми DelPhi [30], що широко використовується в даний час для моделювання електростатичних взаємодій в комплексах біомолекул (див. детальніше в огляді [31]):

$\nabla[\varepsilon(\mathbf{r}) \nabla \varphi(\mathbf{r})]-\frac{8 \pi^{2} I}{k T} \sinh [\varphi(\mathbf{r})]+\frac{4 \pi \rho_{\phi}(\mathbf{r})}{k T}=0$,

де $\varphi$ - безрозмірний електростатичний потенціал в даній точці в одиницях $k T / e ; k$ - стала Больцмана; $T$ - абсолютна температура; $\varepsilon$ - діелектрична проникність середовища; $\rho_{\phi}-$ густина фіксованих зарядів, тобто зарядів даної молекули; $I$ - макроскопічна іонна сила розчину (вдалині від даної молекули); $I=0,1$ M, що відповідає стандартним фізіологічним умовам; $\mathbf{r}$ - радіус-вектор даної точки.

Для системи, що модельована за допомогою НРПБ $(5)$, величина $G_{\mathrm{el}}$ може бути обчислена шляхом об'ємного інтегрування:

$G_{\mathrm{el}}=\iiint_{\infty}\left\{\frac{\rho_{\phi} \varphi_{\phi}}{2}+\rho_{\phi} \varphi_{M}+\frac{\rho_{M} \varphi_{M}}{2}-\left(\rho_{M} \varphi+\right.\right.$ 
$+k T c[2 \cosh (\varphi)-2])\} d V$

де $\varphi_{\phi}$ і $\varphi_{M}$ - потенціали, що створюються фіксованими і рухомими (іонними) зарядами, відповідно, при цьому $\varphi_{\phi}+\varphi_{M}=\varphi ; c-$ концентрація солі; $\rho_{M}-$ густина рухомих зарядів.

НРПБ враховує зміну електричних властивостей найближчої гідратної оболонки молекул при комплексоутворенні, що робить цей метод найбільш переважним для дослідження електростатичних взаємодій у водному розчині [30]. Гідратний шар розділяє область 3 низькою діелектричною проникністю в об'ємі молекули та розчинник $3 \varepsilon_{e}=80$. Метод НРПБ використовує неявне завдання розчинника та метод кінцевих різниць для розв'язання (5). Поляризованість лігандів враховано також неявно шляхом прийняття внутрішньої діелектричної проникності молекул і їх комплексів $\varepsilon_{i}=4$. Величини ВДВ радіусів, необхідні для розрахунку молекулярної поверхні, відповідали силовому полю AMBER [32]. Більш детально методика обчислення $\Delta G_{e l}$, використана у цій роботі, наведена у [31].

\section{6. Обчислення гідрофобної енергї}

Гідрофобна стабілізація комплексів є результатом витіснення води з об'єму комплексу у вільний розчинник, i, як наслідок, гідрофобна енергія носить переважно ентропійний характер.

Розрахунок гідрофобного внеску заснований на існуванні лінійної кореляції між енергією гідрофобного розчинення та зміною площі поверхні, доступної для розчинника (solvent-accessible surface area, $\mathrm{SASA}), \Delta A$ (для огляду див. [33]):

$\Delta G_{\mathrm{hyd}}=\gamma \Delta A$,

де $\gamma$ - мікроскопічний коефіцієнт поверхневого натягу.

Різні автори набувають різних значень $\gamma$, хоча в останні роки більшість дослідників використовують $\gamma=50$ кал/(моль $\AA^{2}$ ) (для огляду див. [15]). Важливо відзначити, що коефіцієнт $\gamma$ найчастіше вимірюється за розподілом у водно-органічній фазі [33], і в зв'язку $з$ цим вже частково враховує також і ентальпійні складники зміни енергії взаємодії "вода-вода" при комплексоутворенні, і ентропійний складник утворення водневих зв'язків на воду.

Площу поверхні, доступної для розчинника, було обчислено з використанням програми GETAREA 1.1
[34]. SASA визначається як геометричне місце центра пробної сфери з радіусом, що дорівнює ван-дерваальсівському радіусові оксигену води $(1,4 \AA)$ при їі русі по поверхні, обмеженій ван-дер-ваальсівськими поверхнями даної молекули.

\section{7. Обчислення енергї̈ водневих зв'язків}

Енергія водневого зв'язку включає в себе ван-дерваальсівський, електростатичний складники, а також специфічні чинники квантово-механічної природи. Часто під час аналізу енергетики комплексоутворення Н-зв'язок умовно виділяють в окремий вид взаємодій, що відрізняється високою специфічністю до структури комплексу.

Водневе зв'язування має два джерела при комплексоутворенні ароматичних молекул:

1. Формування міжмолекулярних Н-зв'язків між лігандами у 1:1 комплексі.

2. Втрата Н-зв'язків з водою через дегідратацію лігандів при утворенні комплексу.

Кількість Н-зв'язків першого типу, $N_{\text {im }}$, що формуються у комплексі, може бути отримано з розрахованої структури та верифіковано за допомогою літературних даних. Усереднена енергія міжмолекулярних Н-зв'язків у оточенні 3 низькою діелектричною проникністю (комплекс) дорівнює приблизно -9 ккал/моль [35]. Отже, енергетичний внесок (ентальпійний за природою) міжмолекулярних Н-зв'язків може бути безпосередньо оцінений як $\Delta G_{\mathrm{im}}=\Delta H_{\mathrm{im}}=-N_{i m} 9$ ккал/моль.

Випадок Н-зв'язків другого типу є більш складним для оцінки. Для визначення енергії Н-зв'язків лігандів з водою у даній роботі обчислено середню кількість молекул води, що формують водневі зв'язки з гідрофільними атомами досліджуваних молекул (гідратаційний індекс $N_{\text {solv }}$ ), протягом останніх 40 пс МД. Наявність водневого зв'язку фіксували, якщо відстані між електронегативними атомами ліганду та атомами оксигену/гідрогену води не перевищувала 3,2/2,4 А відповідно [36]. Різниця між міжмолекулярним Н-зв'язком та Н-зв'язком $з$ водою зумовлена значним негативним ентропійним внеском у вільну енергію останньої внаслідок втрати поступальних та обертальних ступенів вільності молекул води, задіяних у Н-зв'язку [35, 37]. Усереднена енергія Гіббса у водневому зв'язуванні з водою нижча за модулем, ніж ентальпія міжмолекулярного Н-зв'язку у середовищі з низькою діелектричною проникністю і становить приблизно -6 ккал/моль [35]. Отже, відповідна енергія Гіббса $\Delta G_{\text {solv }}=-\Delta N_{\text {solv }} \cdot 6$ ккал/моль і вираз 
для обчислення енергії водневого зв'язування:

$\Delta G_{\mathrm{HB}}=-\left(9 N_{\mathrm{im}}+6 \Delta N_{\mathrm{solv}}\right)$, ккал/моль.

Однак, вираз (8) не може бути використаний безпосередньо для обчислення енергії Н-зв'язку у рівнянні (2) у контексті даної методології. По-перше, ентропійна складова енергії водневого зв'язку вже була врахована при розрахунку гідрофобного внеску (див. вище). По-друге, добре відомо, що електростатичні і ван-дер-ваальсівські енергї (у меншій мірі) є основними вкладниками у енергію Н-зв'язків [38]. Це означає, що обчислення цих енергій з використанням описаної вище методики вже частково враховує ентальпійний складник енергії водневого зв'язку. Як у попередній роботі [15], ми приймаємо, що приблизно $25 \%$ енергії Н-зв'язку недовраховується при розрахунку ван-дер-ваальсівських і електростатичних взаємодій. Середня ентальпія формування водневого зв'язку з водою є дуже близькою до енергії міжмолекулярного Н-зв'язку [35]. Це означає, що кінцевий вираз для складової водневого зв'язування $\Delta \Delta G_{\mathrm{HB}}$, доданий до виразу (2) замість $\Delta G_{\mathrm{HB}}$, набуває вигляду

$\Delta \Delta G_{\mathrm{HB}}=-0,25 \cdot 9\left(N_{\mathrm{im}}+\Delta N_{\text {solv }}\right)$, ккал $/$ моль.

Слід зауважити, що, хоча цей метод для обчислення енергій водневих зв'язків є досить приблизним, він був успішно застосований нами раніше для розділення енергій реакцій комплексоутворення лігандів 3 ДНК [15], що дає підставу для його застосування у даному випадку стекінгу ароматичних молекул. Крім того, оцінка додаткової енергії, що приходиться на один Н-зв'язок $\left(N_{\mathrm{im}}+\Delta N_{\mathrm{solv}}=1\right)$, згідно з $(9)$, становить приблизно 2 ккал/моль, що збігається з аналогічною оцінкою енергетики водневого зв'язування, що визначається експериментально для простих молекул [35].

\section{8. Обчислення ентропійного внеску}

Повний ентропійний внесок у вільну енергію Гіббса комплексоутворення ароматичних молекул є сумою трьох головних компонентів:

$\Delta G_{\mathrm{entr}}=\Delta G_{\mathrm{tr}}+\Delta G_{\mathrm{rot}}+\Delta G_{\mathrm{vib}}$,

де $\Delta G_{\mathrm{tr}}, \Delta G_{\mathrm{rot}}$ та $\Delta G_{\mathrm{vib}}$ є змінами вільних енергій поступальних, обертальних та коливальних ступенів вільності при комплексоутворенні відповідно.

Компоненти $\Delta G_{\text {tr }}$ i $\Delta G_{\text {rot }}$ зумовлені втратою трьох поступальних і трьох обертальних ступенів вільності при комплексоутворенні. 3 загальної точки зору [9],

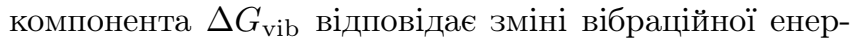
гії при комплексоутворенні, що приводить до формування нових коливальних мод. Однак очевидно, що при цьому головними вкладниками для молекул без масивних бічних ланцюгів є жорсткі ароматичні хромофори. Отже, слід очікувати, що при самоасоціації і стабілізації 1:1 комплексів нековалентними силами молекули можуть мати залишкові коливальні рухи у комплексі. Раніше це було встановлено для комплексів лігандів з ДНК та білками [15]. Отже, виділення у структурі $\Delta G_{\text {entr }}$ складників $\Delta G_{\text {tr }}$ і $\Delta G_{\text {rot }}$, відповідних повній втраті ступенів вільності, є умовним і справедливе тільки якщо в (10) буде додатково враховано енергетику остаточних рухів молекул у комплексах. Одним з можливих підходів до розв'язання цієї задачі є врахування залишкових рухів у формі низькочастотних коливань [39]. Отже, вібраційний внесок у енергію асоціації може бути поділений на дві складові:

$\Delta G_{\mathrm{vib}}=\Delta G_{\mathrm{vib}}^{\mathrm{I}}+\Delta G_{\mathrm{vib}}^{\mathrm{II}}$,

де $\Delta G_{\mathrm{vib}}^{\mathrm{I}}, \Delta G_{\mathrm{vib}}^{\mathrm{II}}$ відповідають зміні коливань хімічних зв'язків (вібрації першого роду) та механічних коливань (вібрації другого роду) відповідно. Оскільки класична частота коливань обернено пропорційна їх масам, вібрації I і II роду також можуть бути визначені як високо- і низькочастотні.

Зміна вільної енергії Гіббса поступальних і обертальних ступенів вільності може бути записана у стандартній формі

$\Delta G_{\mathrm{tr}}=\Delta H_{\mathrm{tr}}-T \Delta S_{\mathrm{tr}}, \quad \Delta G_{\mathrm{rot}}=\Delta H_{\mathrm{rot}}-T \Delta S_{\mathrm{rot}}$,

де $\Delta H_{\mathrm{tr}}=\Delta H_{\mathrm{rot}}=-\frac{3}{2} R T-$ ентальпійні еквіваленти змін поступальних і обертальних ступенів вільності відповідно; $R$ - газова стала; $T$ - абсолютна температура.

Молярну трансляційну ентропію можемо знайти 3 рівняння Сакуре-Тетроде [40]:

$S_{\mathrm{tr}}=R\left[\frac{5}{2}+\frac{3}{2} \ln \frac{2 \pi m k T}{h^{2}}-\ln \frac{N}{V}\right]$

де $N=N_{A}=6,02 \cdot 10^{23}$ моль $^{-1} ; V=10^{-3} \mathrm{~m}^{3} ; k$ i $h$ - сталі Больцмана і Планка відповідно; $m$ - маса молекули.

3 використанням рівняння (13) можна записати вирази для ентропії самоасоціату $X_{2} S_{\mathrm{tr}}^{X_{2}}$ і для вільної молекули $X S_{\mathrm{tr}}^{X}$, що дозволяє отримати вираз для зміни трансляційної ентропї:

$\Delta S_{\mathrm{tr}}=S_{\mathrm{tr}}^{X_{2}}-2 S_{\mathrm{tr}}^{X}=$ 
$=-R\left[\frac{5}{2}+\frac{3}{2} \ln \frac{\pi m k T}{h^{2}}-\ln \frac{N}{V}\right]$.

Вираз для молярної ротаційної ентропії також випливає з класичної статистичної термодинаміки [40]:

$S_{\mathrm{rot}}=R\left[\frac{3}{2}+\frac{1}{2} \ln \pi I_{x} I_{y} I_{z}+\frac{3}{2} \ln \frac{8 \pi^{2} k T}{h^{2}}-\ln \sigma\right]$,

де $I_{x}, I_{y}, I_{z}$ - моменти інерції відносно головних осей інерції, $\sigma$ - параметр симетрії, що дорівнює одиниці для несиметричних комплексів. Величини моментів для лігандів, досліджуваних у даній роботі, обчислено за допомогою програми $X$-PLOR.

Вирази для ентропії і ентальпї вібрацій I роду (коливання хімічних зв'язків) у гармонічному наближенні випливають із класичної статистичної термодинаміки [40]:

$S_{\mathrm{vib}}^{I}=\frac{1}{T} \sum_{j=1}^{3 N-6}\left\{\frac{h \nu_{j}}{e^{h \nu_{j} / k T}-1}-k T \ln \left(1-e^{-h \nu_{j} / k T}\right)\right\}$,

$H_{\mathrm{vib}}^{I}=\sum_{j=1}^{3 N-6}\left(\frac{h \nu_{j}}{e^{h \nu_{j} / k T}-1}+\frac{h \nu_{j}}{2}\right)$

де $N$ - число атомів, $\nu_{j}$ - частоти нормальних мод, обчислені за допомогою пакета Gaussian03W методом PM3.

Отже, у реакції самоасоціації зміни термодинамічних параметрів мають вигляд

$\Delta S_{\mathrm{vib}}^{\mathrm{I}}=S_{\mathrm{vib}}^{X_{2}}-2 S_{\mathrm{vib}}^{X}, \Delta H_{\mathrm{vib}}^{\mathrm{I}}=H_{\mathrm{vib}}^{X_{2}}-2 H_{\mathrm{vib}}^{X}$,

$\Delta G_{\mathrm{vib}}^{\mathrm{I}}=\Delta H_{\mathrm{vib}}^{I}-T \Delta S_{\mathrm{vib}}^{\mathrm{I}}$

Вирази для зміни термодинамічних параметрів вібрацій II роду (низькочастотних) раніше були отримані для комплексоутворення лігандів з ДНК [15] і можуть бути застосовані для реакції самоасоціації в припущенні, що залишкові обертальні рухи молекул у комплексах є малозначущими, і коливання носять гармонійний характер

$\Delta G_{\mathrm{vib}}^{\mathrm{II}}=\Delta H_{\mathrm{vib}}^{\mathrm{II}}-T \Delta S_{\mathrm{vib}}^{\mathrm{II}}, \Delta H_{\mathrm{vib}}^{\mathrm{II}}=R T$,

$\Delta S_{\mathrm{vib}}^{\mathrm{II}}=R \ln \frac{k T}{h \nu_{r}}+R$.

Параметр $\nu_{r}$ у рівнянні (18) - класична частота механічних коливань вздовж координатних осей $r \in$ $(x, y, z)$ :

$\nu_{r}=\frac{1}{2 \pi} \sqrt{\frac{2 K_{r}}{m_{\mathrm{red}}}}$ де $K_{r}$ - силова константа, $m_{\text {red }}$ - зведена маса взаємодіючих молекул, визначається як $\frac{1}{m_{\mathrm{red}}}=\frac{1}{m}+\frac{1}{m}=\frac{2}{m}$.

Величина $K_{r}$ може бути оцінена 3 квадратичної апроксимації потенціальної енергії $U(r)$ у припущенні малих коливань вздовж напрямку $r$ :

$U=U_{0}+K_{r}\left(r-r_{0}\right)^{2}$.

Розрахунок залежності повної енергї міжмолекулярних взаємодій у димері $U(r)$ було виконано за допомогою пакета $X$-PLOR і потім було апроксимовано рівнянням (20) для отримання значень $K_{r}$. Подальше обчислення $\nu_{r}$ за рівнянням (19) дозволяє отримати термодинамічні параметри згідно з рівняннями (18).

\section{3. Результати та обговорення}

\section{1. Аналіз ван-дер-ваалъсівсъкої енергї $\left(\Delta G_{\mathrm{VdW}}\right)$}

Результати обчислення складової $\Delta G_{\mathrm{VdW}}$ подано у табл. 1. Як видно, енергії сольватації $\Delta G_{\text {solv }}^{X}$ i $\Delta G_{\text {solv }}^{X_{2}}$ для молекули $X$ і їі димеру $X_{2}$, відповідно, і міжмолекулярних взаємодій у вакуумі $\Delta G_{\mathrm{im}} \in$ негативними для всіх досліджуваних систем. Це відбиває характер тяжіння ВДВ сил між взаємодіючими молекулами (розчинник-ліганд для сольватаційної енергії і ліганд-ліганд для міжмолекулярної). Однак повна зміна сольватаційної енергії $\Delta G_{\text {solv }}$ у реакції (1) завжди позитивна та зумовлена втратою вигідних ВДВ контактів ліганду з молекулами води при утворенні комплексу. Цей ефект є добре відомим для реакцій зв'язування лігандів з ДНК під назвою "десольватація".

Важливо відзначити, що величини сольватаційного $\left(\Delta G_{\text {solv }}\right)$ та міжмолекулярного $\left(\Delta G_{\text {im }}\right)$ складників

Т а б л и ц 1. Розрахункові складники ван-дерваальсівської енергії (ккал/моль)

\begin{tabular}{c|c|c|c|c|c}
\hline Сполука & $\Delta G_{\text {solv }}^{X}$ & $\Delta G_{\text {solv }}^{X_{2}}$ & $\Delta G_{\text {solv }}$ & $\Delta G_{\mathrm{im}}$ & $\Delta G_{\mathrm{VdW}}$ \\
\hline AMD & $-117,3$ & $-197,7$ & 36,9 & $-32,9$ & 4,0 \\
DAU & $-55,6$ & $-77,3$ & 33,9 & $-33,7$ & 0,2 \\
DOX & $-55,5$ & $-78,4$ & 32,7 & $-31,5$ & 1,1 \\
NOG & $-79,9$ & $-121,5$ & 38,3 & $-40,5$ & $-2,2$ \\
NOR & $-41,2$ & $-63,1$ & 19,2 & $-18,1$ & 1,1 \\
NOV & $-55,3$ & $-83,5$ & 27,2 & $-26,5$ & 0,7 \\
AO & $-31,4$ & $-45,4$ & 17,3 & $-15,6$ & 1,7 \\
EB & $-37,4$ & $-54,0$ & 20,8 & $-18,5$ & 2,3 \\
PF & $-23,2$ & $-36,5$ & 9,9 & $-12,0$ & $-2,0$ \\
PI & $-58,4$ & $-93,8$ & 22,9 & $-19,1$ & 3,8 \\
CAF & $-26,1$ & $-40,6$ & 11,5 & $-13,7$ & $-2,1$ \\
FMN & $-54,2$ & $-82,9$ & 25,4 & $-30,1$ & $-4,7$ \\
\hline
\end{tabular}


(див. табл. 1) мають протилежні знаки та близькі за модулем, що приводить до невеликої повної ВДВ енергії $\Delta G_{\mathrm{VdW}}$ з різними знаками, які залежать від типу взаємодіючих молекул. Подібний висновок було зроблено раніше для комплексоутворення ароматичних лігандів з ДНК (див. [15] та посилання у ній). У результаті можна виділити два основних висновки:

1. Повна ВДВ енергія $\Delta G_{\mathrm{VdW}}$ стекінгу ароматичних сполук визначається тонким балансом між міжмолекулярною взаємодією та взаємодією з розчинником. Беручи до уваги те, що значення $\Delta G_{\mathrm{VdW}} \in$ piзницею двох великих чисел, аналіз повної ВДВ енергї $\Delta G_{\mathrm{VdW}}$ навряд чи $є$ значущим - тільки аналіз сольватаційного $\left(\Delta G_{\text {solv }}\right)$ і міжмолекулярного $\left(\Delta G_{\text {im }}\right)$ складників ВДВ енергії може мати фізичний сенс.

2. Однак точка зору про те, що ВДВ сили не дають внеску у стабілізацію стекінгу ароматичних сполук, $є$ некоректною. Як було показано вище, складова $\Delta G_{\text {im }}$ забезпечує важливий внесок у стабілізацію димерних комплексів. Це також підтверджується квантово-механічними розрахунками взаємодій між різними ароматичними сполуками $[13,41,42]$.

\section{2. Аналіз електростатичної енергї ( $\left.\Delta G_{\mathrm{el}}\right)$}

Результати обчислення складової $\Delta G_{\mathrm{el}}$ наведено у табл. 2. Сольватаційні енергії $\Delta G_{\text {solv }}^{X}$ i $\Delta G_{\text {solv }}^{X_{2}}$ мають якісно ту саму тенденцію, яка була описана вище для ВДВ енергіі, а саме вигідні (тяжіння) взаємодії $X$ та $X_{2}$ з молекулами розчинника, зумовлені іондипольними i/або диполь-дипольними взаємодіями. Важливо відзначити, що $\Delta G_{\text {solv }}$ утворена різницею двох великих чисел, тобто $\Delta G_{\mathrm{solv}}^{X_{2}}-2 \Delta G_{\mathrm{solv}}^{X}$. Тому, на противагу ВДВ сольватаційній енергії, сольватаційна електростатична енергія $\left(\Delta G_{\text {solv }}\right)$ може бути як пози-

Т а б ли ц я 2. Розрахункові складники електростатичної енергії (ккал/моль)

\begin{tabular}{ccc|c|c|c|c|c}
\hline Сполука & Заряд & $\Delta G_{\text {solv }}^{X}$ & $\Delta G_{\text {solv }}^{X_{2}}$ & $\Delta G_{\text {solv }}$ & $\Delta G_{\text {im }}$ & $\Delta G_{\mathrm{el}}$ \\
\hline AMD & 0 & $-1724,9$ & $-3449,2$ & 0,5 & 0,8 & 1,3 \\
DAU & +1 & $-660,7$ & $-1328,1$ & $-6,7$ & 9,9 & 3,1 \\
DOX & +1 & $-797,4$ & $-1602,6$ & $-7,7$ & 11,6 & 3,9 \\
NOG & +1 & $-939,9$ & $-1885,9$ & $-6,1$ & 11,2 & 5,1 \\
NOR & 0 & $-276,6$ & $-551,5$ & 1,6 & $-1,3$ & 0,3 \\
NOV & 0 & $-591,7$ & $-1179,4$ & 4,1 & $-3,9$ & 0,2 \\
AO & +1 & $-165,2$ & $-341,7$ & $-11,2$ & 12,2 & 1,0 \\
EB & +1 & $-427,5$ & $-864,5$ & $-9,6$ & 11,4 & 1,9 \\
PF & +1 & $-379,8$ & $-770,5$ & $-10,9$ & 12,3 & 1,4 \\
PI & +2 & $-483,1$ & $-998,2$ & $-32,0$ & 35,2 & 3,2 \\
CAF & 0 & $-164,1$ & $-328,2$ & 0,0 & 0,5 & 0,6 \\
FMN & -2 & $-811,2$ & $-1651,3$ & $-29,0$ & 36,4 & 7,4 \\
\hline
\end{tabular}

тивною, так і негативною для різних систем. У даному випадку не виявляється чіткого ефекту “десольватаціі”, що може очікуватися при частковому видаленні вигідних електростатичних (і ВДВ) взаємодій "вода-ліганд" при формуванні комплексу.

Аналіз значень $\Delta G_{\text {solv }}$ у табл. 2 дозволив виділити їі кореляцію з зарядами взаємодіючих молекул. $\Delta G_{\text {solv }} є$ завжди негативною, якщо молекули лігандів $\epsilon$ зарядженими. Найбільші значення $\Delta G_{\text {solv }}$ спостерігаються для димерів молекул FMN та PI, які мають подвійні негативний та позитивний заряди відповідно. Це явище може бути пояснене, якщо взяти до уваги, що при комплексоутворенні молекул з однаковими зарядами зарядова густина комплексу збільшується. Це приводить до енергетично вигідних взаємодій з розчинником. Цей ефект переважає невигідну енергію десольватації, даючи у сумі негативну повну енергію $\Delta G_{\mathrm{el}}$. Така поведінка подібна до тієї, що раніше спостерігалася під час дослідження самоасоціації деяких ароматичних лігандів [8] і їх комплексоутворення з дуплексною ДНК $[31,43]$.

Енергія електростатичних міжмолекулярних взає-

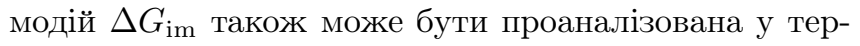
мінах їі кореляції з зарядами взаємодіючих молекул. $\Delta G_{\mathrm{im}}$ є завжди позитивною та відносно великою, якщо молекули лігандів заряджені, тобто це є просто ефект електростатичного відштовхування. Як і очікувалося, найбільші значення $\Delta G_{\mathrm{im}}$ спостерігаються для димерів FMN та PI, що також відповідає найбільшій енергії $\Delta G_{\text {solv }}$ для цих систем.

$\mathrm{У}$ цілому можна зробити висновок, що сольватаційна та міжмолекулярна електростатичні енергії виявляють виражену залежність від зарядів взаємодіючих молекул. Навпаки, повна електростатична енергія $\Delta G_{\text {el }}$ є малою, для більшості систем позитивною та не має ніякої кореляції з типом і зарядом молекул. Це означає, що аналіз $\Delta G_{\mathrm{el}}$ не $є$ фізично значущим для стекінг-взаємодії ароматичних сполук, на що вказувалося вище для повної ВДВ енергії і повідомлялося раніше для інтеркаляції лігандів у ДНК (для огляду див. [31]) і стекінгу азотистих основ [44].

Аналіз результатів для ароматичних систем у табл. 2 дозволяє зробити висновок, що електростатична стабілізація самоасоціатів зумовлена взаємодією з розчинником, тоді як ВДВ завжди має міжмолекулярну природу.

\section{3. Аналіз гідрофобної енергї ( $\left.\Delta G_{\mathrm{hyd}}\right)$}

Результати обчислення значень $\Delta A$ і $\Delta G_{\text {hyd }}$ наведено в табл. 3. Для всіх досліджуваних систем гідро- 
фобний внесок є енергетично вигідним i, у середньому вищий за модулем, ніж ВДВ та електростатичний складники $\Delta G_{\text {solv }}$ і $\Delta G_{\text {im }}$, що впливає на стабілізацію комплексів (див. табл. 1, 2 та обговорення вище). Цей результат у цілому узгоджується з точкою зору [45], що класичний гідрофобний ефект стабілізує стекінг ароматичних сполук у водному розчині, i пояснюється зменшенням $\Delta A$ взаємодіючих молекул при утворенні комплексу (див. табл. 3).

\section{4. Аналіз енергї̈ водневого зв'язування $\left(\Delta G_{\mathrm{HB}}\right)$}

Результати розрахунку складової $\Delta G_{\mathrm{HB}}$ зведені в табл. 4. Середне число молекул води (гідратаційний індекс $N_{\text {solv }}$ ), які формують Н-зв'язки $з$ молекулою ліганду, залежить від кількості сайтів гідратації та якісно корелює з молекулярною масою досліджуваних молекул, будучи найвищою для AMD, DAU i DOX та найменшою для молекул CAF та PF. Як i очікувалося, зміна гідратації $\Delta N_{\text {solv }}$ при комплексоутворенні є негативною, відбиваючи видалення молекул води та відповідну втрату Н-зв'язків з водою (десольватація). Це узгоджується з поведінкою сольватаційного складника $\Delta G_{\text {solv }}$, що обговорювалося вище для ВДВ, електростатичних та гідрофобних взаємодій. Десольватація частково компенсується утворенням міжмолекулярних Н-зв'язків, як у випадку антибіотика $\mathrm{NOV}\left(N_{\mathrm{im}}=2\right)$, хоча сумарний ефект $\left(\Delta G_{\mathrm{HB}}\right)$ водневого зв'язування для досліджуваних комплексів ароматичних сполук є енергетично невигідним.

Т а б л и ц я 3. Розрахункові складники гідрофобної та ентропійної енергій $(\Delta G$, ккал/моль) і зміни площі поверхні, доступної для розчинника $\left(\Delta A, \AA^{2}\right)$

\begin{tabular}{c|cc|cccccc}
\hline \multirow{2}{*}{ Сполука } & \multicolumn{2}{|c|}{ Гідрофобний } & \multicolumn{5}{|c}{ Ентропійний } \\
\cline { 2 - 8 } & $\Delta A$ & $\Delta G_{\mathrm{hyd}}$ & $\Delta G_{\mathrm{tr}}$ & $\Delta G_{\mathrm{rot}}$ & $\Delta G_{\mathrm{vib}}^{\mathrm{I}}$ & $\Delta G_{\mathrm{vib}}^{\mathrm{II}}$ & $\Delta G_{\mathrm{entr}}$ \\
\hline AMD & $-552,9$ & $-27,6$ & 10,7 & 10,2 & $-2,9$ & $-8,1$ & 9,9 \\
DAU & $-532,0$ & $-26,6$ & 9,9 & 9,5 & $-4,3$ & $-9,2$ & 5,9 \\
DOX & $-428,4$ & $-21,4$ & 9,9 & 9,5 & $-1,1$ & $-9,5$ & 8,8 \\
NOG & $-566,9$ & $-28,3$ & 10,3 & 10,6 & $-3,0$ & $-8,7$ & 9,2 \\
NOR & $-252,4$ & $-12,6$ & 9,4 & 8,6 & $-3,8$ & $-10,4$ & 3,8 \\
NOV & $-400,2$ & $-20,0$ & 9,8 & 9,6 & $-2,0$ & $-8,1$ & 9,3 \\
AO & $-283,1$ & $-14,2$ & 9,3 & 8,1 & $-3,6$ & $-8,9$ & 4,8 \\
EB & $-317,5$ & $-15,9$ & 9,5 & 8,6 & $-2,8$ & $-10,7$ & 4,5 \\
PF & $-234,8$ & $-11,7$ & 9,1 & 7,5 & $-3,0$ & $-10,4$ & 3,2 \\
PI & $-319,3$ & $-16,0$ & 9,7 & 8,9 & $-1,6$ & $-11,3$ & 5,7 \\
CAF & $-217,2$ & $-10,9$ & 9,0 & 7,4 & $-2,0$ & $-10,7$ & 3,7 \\
FMN & $-339,1$ & $-17,0$ & 9,8 & 9,1 & $-2,6$ & $-9,5$ & 6,7 \\
\hline
\end{tabular}

\section{5. Аналіз ентропійного внеску}

Результати обчислення складової $\Delta G_{\text {entr }}$ наведено в табл. 3. Як і очікувалося, енергії, відповідні втраті поступальних $\Delta G_{\mathrm{tr}}$ та обертальних $\Delta G_{\text {rot }}$ ступенів вільності, є невигідними, тоді як утворення нових коливальних мод хімічних зв'язків $\Delta G_{\mathrm{vib}}^{I}$ і механічних коливань $\Delta G_{\mathrm{vib}}^{\mathrm{II}}$ сприятливі. Важливо, що всі чотири ентропійні складники є близькими за модулем експериментальній енергії $\Delta G_{\text {exp }}$ при утворенні комплексу (див. табл. 5). Це вимагає обов'язкового врахування цих складових при аналізі енергетики стекінгвзаємодії ароматичних сполук.

Сумарний внесок всіх ентропійних чинників $\Delta G_{\mathrm{entr}}$ $є$ позитивним внаслідок енергетично невигідної втрати поступальних та обертальних ступенів вільності.

\section{6. Аналіз повної енергї димеризащї}

$\mathrm{y}$ табл. 5 наведено експериментальну енергію $\Delta G_{\text {exp }}$, повну розрахункову енергію $\Delta G_{\text {total }}$ і сумарні внески у повну енергію від різних фізичних чинників, задіяних у комплексоутворенні досліджуваних молекул. Беручи до уваги, що величина $\Delta \Delta G_{\mathrm{HB}}$ не має свого власного фізичного сенсу, і що основним вкладником у енергію водневого зв'язування є електростатичний компонент, ці два внески об'єднані в табл. 5 як $\Delta G_{\mathrm{el}}+\Delta \Delta G_{\mathrm{HB}}=\Delta G_{\mathrm{el}+\mathrm{HB}}$.

Представляється необхідним визначити, чи є задовільною відповідність між експериментальними і теоретичними значеннями. Хоча важко розрахувати точно похибку обчислених абсолютних енергій, очікується, що похибка сумарних енергій становить декіль-

Т а б ли ц я 4. Розрахункові складники енергї водневого зв'язування ( $\Delta G$, ккал/моль) і гідратаційних індексів $(N)$

\begin{tabular}{ccccccccc}
\hline Сполука & $\Delta N_{\text {solv }}^{X}$ & $\Delta N_{\text {solv }}^{X_{2}}$ & $\Delta N_{\text {solv }}$ & $N_{i m}$ & $\Delta G_{\mathrm{HB}}$ & $\Delta \Delta G_{\mathrm{HB}}$ \\
\hline AMD & 11,8 & 21,5 & $-2,1$ & 0 & 12,8 & 4,8 \\
DAU & 12,4 & 19,2 & $-5,6$ & 0 & 33,7 & 12,6 \\
DOX & 12,8 & 23,4 & $-2,2$ & 0 & 13,4 & 5,0 \\
NOG & 10,8 & 16,5 & $-5,1$ & 0 & 30,5 & 11,4 \\
NOR & 4,6 & 7,5 & $-1,8$ & 0 & 10,6 & 4,0 \\
NOV & 8,8 & 14,3 & $-3,3$ & 2 & 1,6 & 2,9 \\
AO & 2,8 & 5,7 & 0,0 & 0 & 0,0 & 0,0 \\
EB & 5,9 & 10,6 & $-1,2$ & 0 & 7,3 & 2,7 \\
PF & 6,4 & 10,7 & $-2,1$ & 0 & 12,8 & 4,8 \\
PI & 1,6 & 2,4 & $-0,8$ & 0 & 5,0 & 1,9 \\
CAF & 1,5 & 1,1 & $-1,9$ & 0 & 11,7 & 4,4 \\
FMN & 3,2 & 4,4 & $-2,0$ & 0 & 12,2 & 4,6 \\
\hline
\end{tabular}

П р и м і тк а: значення числа міжмолекулярних водневих зв'язків $N_{\mathrm{im}}$ взято з посилань в табл. 5 
Т а б ли ц я 5. Розрахункові складники повної енергії (ккал/моль)

\begin{tabular}{|c|c|c|c|c|c|c|c|}
\hline Сполука & $\Delta G_{\mathrm{VdW}}$ & $\Delta G_{\mathrm{el}+\mathrm{HB}}$ & $\Delta G_{\text {hyd }}$ & $\Delta G_{\text {entr }}$ & $\Delta G_{\text {total }}$ & $\Delta G_{\exp }$ & $\mid \Delta G_{\text {total }}-\Delta G_{\text {exp }}$ \\
\hline AMD & 4,0 & 6,0 & $-27,6$ & 9,9 & $-7,7$ & $-4,3[20]$ & 3,4 \\
\hline $\mathrm{DAU}$ & 0,2 & 15,8 & $-26,6$ & 5,9 & $-4,7$ & $-3,9[20]$ & 0,8 \\
\hline DOX & 1,1 & 8,9 & $-21,4$ & 8,8 & $-2,5$ & $-4,4[20]$ & 1,9 \\
\hline NOG & $-2,2$ & 16,5 & $-28,3$ & 9,2 & $-4,7$ & $-5,1[20]$ & 0,4 \\
\hline NOR & 1,1 & 4,3 & $-12,6$ & 3,8 & $-3,5$ & $-2,9[46]$ & 0,6 \\
\hline $\mathrm{NOV}$ & 0,7 & 3,1 & $-20,0$ & 9,3 & $-6,9$ & $-6,1[20]$ & 0,8 \\
\hline EB & 2,3 & 4,6 & $-15,9$ & 4,5 & $-4,4$ & $-3,4[20]$ & 1,0 \\
\hline $\mathrm{PF}$ & $-2,0$ & 6,2 & $-11,7$ & 3,2 & $-4,4$ & $-3,8[20]$ & 0,6 \\
\hline PI & 3,8 & 5,0 & $-16,0$ & 5,7 & $-1,4$ & $-2,5[19]$ & 1,1 \\
\hline $\mathrm{CAF}$ & $-2,1$ & 4,9 & $-10,9$ & 3,7 & $-4,4$ & $-1,5[20]$ & 2,9 \\
\hline FMN & $-4,7$ & 12,0 & $-17,0$ & 6,7 & $-2,9$ & $-3,3[20]$ & 0,4 \\
\hline
\end{tabular}

ка ккал/моль. Попередні дослідження також підтвердили, що похибка приблизно у декілька ккал/моль є властивою при використанні моделі неявного розчинника (метод НРПБ) з зарядженими молекулами лігандів [8], як і у даному випадку. Різниця між значеннями експериментальної та розрахункової вільної енергї $\left|\Delta G_{\exp }-\Delta G_{\text {total }}\right|$ для кожної молекулярної системи наведено у табл. 5. Головним результатом аналізу є те, що для всіх вивчених систем має місце задовільна (у межах декількох ккал/моль) відповідність між теорією і експериментом: середнє відхилення розрахунку від експерименту становить $\mid \Delta G_{\exp }-$ $\Delta G_{\text {total }} \mid=1,3$ ккал $/$ моль, а середній розкид експериментальних значень становить $\left|\Delta G_{\text {exp }}-\overline{\Delta G_{\text {exp }}}\right|=1,0$ ккал/моль. Найбільше розходження спостерігається для антибіотика актиноміцину D, що, мабуть, пов'язане з додатковим впливом масивних пентапептидних лактонних кілець (див. рис. 2,2), який не враховується в енергетичному аналізі. В цілому це означає, що методологія, використана у даній роботі, "відстежує" експеримент і що аналіз енергетичних складників від різних фізичних чинників є фізично значущим. Важливо також відзначити, що алгоритм, застосований у даній роботі для розділення енергї заснований на різних методах, незалежних один від одного: неемпіричних (НРПБ та рівняння (10)), напівемпіричних (силове поле для ВДВ енергій) і емпіричних (рівняння (7), (9)). Дана методологія виключає будь-який внесок систематичної похибки, яка може мати місце при використанні лише одного методу (наприклад, обчислення енергї виключно з МД).

Як видно з табл. 5, з чотирьох сумарних внесків у повну енергію гідрофобний є переважаючим для всіх досліджуваних систем і енергетично вигідним. Основна дестабілізація виникає внаслідок повного внеску електростатики разом із водневим зв'язува- нням та втратою ступенів вільності $\Delta G_{\text {entr }}$. Однак, як обговорювалося вище, аналіз сумарної енергї не дає відповіді на запитання: які фізичні чинники стабілізують/дестабілізують стекінг ароматичних молекул та яка їх відносна важливість. Продемонструємо відповідь на це запитання на прикладі двох різних молекулярних систем. Зауважимо також, що внесок водневих зв'язків і ентропійних чинників $\epsilon$ завжди несприятливим для всіх досліджуваних систем.

Димер DAU. Основна стабілізація забезпечується міжмолекулярними ВДВ взаємодіями $\Delta G_{\mathrm{VdW}}^{\mathrm{im}}$ та, у меншій мірі, гідрофобними взаємодіями $\Delta G_{\mathrm{hyd}}$ та електростатичними взаємодіями з розчинником $\Delta G_{\mathrm{el}}^{\text {solv }}$. ВДВ взаємодії з розчинником $\Delta G_{\mathrm{VdW}}^{\text {solv }}$ та електростатичні міжмолекулярні взаємодії $\Delta G_{\mathrm{el}}^{\mathrm{im}} \epsilon$ енергетично невигідними.

Димер PI. Основна стабілізація забезпечується електростатичною взаємодією з розчинником $\Delta G_{\mathrm{el}}^{\mathrm{solv}} \mathrm{i}, \mathrm{y}$ меншій мірі, практично порівну, гідрофобними взаємодіями $\Delta G_{\mathrm{hyd}}$ і міжмолекулярними ВДВ $\Delta G_{\mathrm{VdW}}^{\mathrm{im}}$. ВДВ взаємодії з розчинником $\Delta G_{\mathrm{VdW}}^{\text {solv }}$ та електростатичні міжмолекулярні взаємодії $\Delta G_{\mathrm{el}}^{\mathrm{im}} є$ енергетично невигідними.

У цілому, стабілізуючі та дестабілізуючі чинники залежать від досліджуваної молекулярної системи та можуть мати ВДВ, електростатичну або гідрофобну природу. Результати даної роботи забезпечують розуміння ролі різних фізичних чинників, задіяних у стабілізації стекінгу ароматичних молекул.

\section{4. Висновки}

1. Розроблена методика обчислення вільної енергії стекінгу ароматичних сполук, зумовленої внесками різних фізичних чинників. Важливо відзначи- 
ти, що ця методика враховує найбільш повний набір типів фізичних взаємодій у розчині: ван-дерваальсівські, електростатичні, гідрофобні, водневе зв'язування (міжмолекулярне і з розчинником), енергетичний еквівалент втрати та появи ступенів вільності при комплексоутворенні. Вона поєднує в собі неемпіричні, напівемпіричні та емпіричні методи, що суттєво зменшує будь-яку систематичну похибку, можливу при використанні лише одного обчислювального методу. Іншою особливістю даної методики є успішна верифікація з експериментальними даними для 12 молекул з різними структурами та зарядовими станами. Це означає, що величини розрахованих компонентів повних енергій є значущими та їх аналіз має фізичний сенс. За нашими даними, на сьогоднішній день не існує аналогічної методики для аналізу енергій стекінг-взаємодії ароматичних молекул.

2. Аналіз розрахованих енергії дає відповідь на питання: які фізичні чинники стабілізують/дестабілізують стекінг ароматичних молекул у розчині, та яка їх відносна важливість. Встановлено, що стабілізуючі та дестабілізуючі чинники залежать від досліджуваної системи та можуть мати ван-дер-ваальсівську, електростатичну або гідрофобну природу, тоді як внески водневих зв'язків та ентропійних чинників є завжди несприятливими.

Висловлюємо подяку рецензентові за конструктивні зауваження.

1. P. Yakovchuk, E. Protozanova, and M.D. FrankKamenetskii, Nucleic Acids Res. 34, 564 (2006).

2. D.E. Graves and L.M. Velea, Curr. Org. Chem. 4, 915 (2000).

3. T.F.A. De Greef, M.M.J. Smulders, M. Wolffs et al., Chem. Rev. 109, 5687 (2009).

4. E. Meyer, R.K. Castellano, and F. Diederich, Angew. Chem. Int. Ed. 42, 1210 (2003).

5. N. Lane and T.C. Jenkins, Quart. Rev. Biophys. 33, 255 (2000).

6. H.-J. Schneider, Angew. Chem. Int. Ed. 48, 3924 (2009).

7. S.L. McKay, B. Haptonstall, and S.H. Gellman, J. Am. Chem. Soc. 123, 1244 (2001).

8. E. Buisine, K. de Villiers, T.G. Egan et al., J. Am. Chem. Soc. 128, 12122 (2006).

9. S.Yu. Noskov and C. Lim, Biophys. J. 81, 737 (2001).

10. B. Jayaram, K.J. McConnell, S.B. Dixit et al., J. Comput. Phys. 151, 333 (1999).

11. I. Haq, Arch. Biochem. Biophys. 403, 1 (2002).

12. W. Treesuwan, K. Wittayanarakul, N.G. Anthony et al., Phys. Chem. Chem. Phys. 11, 10682 (2009).
13. S. Tsuzuki, K. Honda, T. Uchimaru, and M. Mikami, J. Chem. Phys. 125, 124304 (2006)

14. D. Mackie and G.A. DiLabio, J. Phys. Chem. A. 112, 10968 (2008).

15. V.V. Kostjukov, N.M. Khomytova, and M.P. Evstigneev, Biopolymers 91, 773 (2009).

16. M.P. Evstigneev, V.P. Evstigneev, and D.B. Davies, J. Chem. Phys. 127, 154511 (2007).

17. R.B. Martin, Chem. Rev. 96, 3043 (1996).

18. D.L. Mobley and K.A. Dill, Structure 17, 489 (2009).

19. M.P. Evstigneev, D.B. Davies, and A.N. Veselkov, Chem. Phys. 321, 25 (2006).

20. M.P. Evstigneev, V.P. Evstigneev, A.O. Lantushenko, et al., Biophys. Chem. 132, 148 (2008).

21. R. Sangvi, D. Evans, and S.H. Yalkowski, Int. J. Pharm. Sci. 336, 35 (2007).

22. Tewari and R. Dubey, Bioorg. Med. Chem. 16, 126 (2008).

23. T. Brunger, X-PLOR: A System for X-ray Crystallography and NMR (Yale University Press, Yale, 1992).

24. M. P. Evstigneev, Yu.V. Mukhina, and D.B. Davies, Mol. Phys. 104, 647 (2006).

25. R. Brooks, R.E. Bruccoleri, B.D. Olafson et al., J. Comput. Chem. 4, 187 (1983).

26. E. Sigfridsson and U. Ryde, J. Comput. Chem. 19, 377 (1998).

27. N.L. Allinger, J. Am. Chem. Soc. 99, 8127 (1977).

28. L. Verlet, Phys. Rev. 159, 98 (1967).

29. J.-P. Ryckaert, G. Ciccotti, and H.J.C. Berendsen, J. Comput. Phys. 23, 327 (1977).

30. W. Rocchia, E. Alexov, and B. Honig, J. Phys. Chem. B 105, 6507 (2001).

31. V.V. Kostjukov, N.M. Khomytova, D.B. Davies, and M.P. Evstigneev, Biopolymers 89, 680 (2008).

32. W.D. Cornell, P. Cieplak, C.I. Bayly et al., J. Am. Chem. Soc. 117, 5179 (1995).

33. K.A. Sharp, A. Nicholls, R.F. Fine et al., Science 252, 106 (1991).

34. R. Fraczkiewicz and W. Braun, J. Comput. Chem. 19, 319 (1998).

35. G.I. Makhatadze and P.L. Privalov, Adv. Protein. Chem. 47, 307 (1995).

36. A.V. Teplukhin, V.I. Poltev, and V.P. Chuprina, Biopolymers 31, 1445 (1991).

37. T.V. Chalikian, Biopolymers 70, 492 (2003).

38. P.A. Kollman and L.C. Allen, Chem. Rev. 72, 283 (1972).

39. В.В. Костюков, Н.М. Хомутова, М.П. Евстигнеев, Хим. физика 28, 26 (2009).

ISSN 2071-0194. Укр. фіз. журн. 2011. Т. 56, №1 
40. A. Maczek, Statistical Thermodynamics (Oxford University Press, Oxford, 1998).

41. C. Alhambra, F.J. Luque, F. Gago et al., J. Phys. Chem. B 101, 3846 (1997).

42. H. Sun, Y. Zhao, Z. Huang et al., J. Phys. Chem. A 112 , 11382 (2008).

43. M. Baginski, F. Fogolari, and J.M. Briggs, J. Mol. Biol. 274, 253 (1997).

44. R. A. Friedman and B. Honig, Biophys. J. 9, 1528 (1995).

45. W. J.B. Blokzijl and F.N. Engberts, Angew. Chem. Int. Ed. 32, 1545 (1993).

46. M.P. Evstigneev, K.A. Rybakova, and D.B. Davies, Biophys. Chem. 121, 84 (2006).

Одержано 28.05.10

\section{ЭНЕРГЕТИЧЕСКИЙ}

АНАЛИЗ КОМПЛЕКСООБРАЗОВАНИЯ

АРОМАТИЧЕСКИХ МОЛЕКУЛ В ВОДНОМ РАСТВОРЕ

В.В. Костюков, Н.М. Твердохлеб, М.П. Евстигнеев

$\mathrm{P}$ е $з$ ю е

Представлен анализ энергетики нековалентных взаимодействий при самоассоциации 12 ароматических молекул, разных по структуре и заряду. Разработана методика вычисления вкладов различных физических факторов в полную энергию Гиббса. Выявлено, что вклады водородных связей и энтропийные факторы всегда являются благоприятными, в то время как ван-дер-ваальсовские, электростатические и (или) гидрофобные взаимодействия могут быть стабилизирующими или дестабилизирующими факторами в зависимости от исследуемой системы. Анализ, проведенный в данной работе, дает ответ на вопрос: какие факторы стабилизируют/дестабилизируют стэкинг ароматических молекул в растворе, и какова их относительная важность.

ENERGY ANALYSIS OF THE COMPLEX FORMATION OF AROMATIC MOLECULES IN AN AQUEOUS SOLUTION

V.V. Kostjukov, N.M. Tverdokhleb, M.P. Evstigneev

Sevastopol National Technical University

(33, Universytets'ka Str., Sevastopol 99053, Ukraine)

$\mathrm{S} \mathrm{u} \mathrm{m} \mathrm{m} \mathrm{a} \mathrm{r} \mathrm{y}$

The energetics of noncovalent interactions at the self-association of aromatic molecules with various structures and charges has been analyzed. Twelve different molecules have been examined. A method to compute the contributions made by various physical factors to the total Gibbs energy has been developed. The contributions given by hydrogen bonds and entropic factors were found to be always favorable, whereas the contributions made by van der Waals, electrostatic, and/or hydrophobic effects may be stabilizing or destabilizing, depending on the specific system under consideration. The issues concerning the factors that stabilize/destabilize the stacking of aromatic molecules in the solution and their relative importance have been elucidated. 